Int. J. Dev. Biol. 55: 781-789

doi: $10.1387 /$ ijdb.113364as

\title{
Insulin-like growth factor binding proteins and mammary gland development
}

\author{
ANGARA SURESHBABU, ELIZABETH TONNER and DAVID J. FLINT* \\ Strathclyde Institute of Pharmacy and Biomedical Sciences, University of Strathclyde, UK
}

\begin{abstract}
Mammary gland development is dependent upon insulin-like growth factors (IGFs) as survival factors. The actions of the IGFs are modulated by a family of IGF-binding proteins (IGFBP1-6). Expression of the IGFBPs is both time-dependent and cell-specific during both the developmental phases and the involution of the mammary gland. Although studied extensively in vitro, understanding the roles of IGFBPs in vivo has been difficult, largely due to the fact that IGFBP knock-out mice have no dramatic phenotypes. This review examines the evidence from in vitro studies and the attempts to examine in vivo actions utilising models with IGFBP deficiency or over-expression. In vitro studies demonstrate that IGFBPs can act by inhibition of the survival effects of IGFs, as well as by enhancing the effects of IGFs. Because the IGFBPs are found associated with the extracellular matrix, a role for IGFBPs as a reservoir of IGFs or, alternatively as a potential barrier to IGFs, thereby restricting their entry into particular tissues or cellular compartments was postulated. We also provide evidence with respect to the IGF-independent actions of the IGFBPs which include receptors, nuclear localization, and interaction with the extracellular matrix and cell surface proteins including integrins. We believe that recent findings place some of the IGFBPs in a larger family of extracellular proteins, the secreted cysteine-rich protein (CCN) family, which have similar structural domains (involved in binding to IGFs, extracellular matrix and integrins) and are heavily implicated in tissue re-modeling and morphogenesis.
\end{abstract}

KEY WORDS: apoptosis, extracellular matrix, proteolysis, CCN, integrin

\section{Insulin-like growth factor binding proteins: an overview}

There are 6 IGF binding proteins (IGFBPs) which vary in length from 201-289 residues. They bind IGFs with high affinity $\left(K_{D} \sim\right.$ $10^{-10} \mathrm{M}$ ) and over $95 \%$ of IGFs in serum and other biological fluids are bound to IGFBPs. The affinity of IGFBPs for IGFs is typically 10-fold higher than that of the type I IGF-receptor and thus IGFs bound to IGFBPs probably have limited access to cell surface receptors. However, IGFBPs also bind to extracellular matrix (ECM) glycosaminoglycans (GAGs) and other ECM proteins (Arai et al., 1994) which can reduce the affinity of IGF-IGFBP binding and potentially increase bioavailability of IGFs. The IGF axis also includes a group of IGFBP proteases which act to cleave IGFBPs, which also results in a large reduction in affinity between IGFBPs and IGFs. In addition to the direct interaction of IGFBPs with IGFs, IGFBPs also have IGF-independent effects in some tissues (Mohan et al., 1995). As a consequence, IGFBPs serve roles which extend well beyond that of simple carriers or distributors of IGFs.

\section{Mammary gland development: an overview}

The development of the mammary gland is a complex process in which it undergoes a series of dynamic and unique developmental features. As with most tissues there is embryonic development but the mammary gland also has additional and considerable postnatal developmental phases at puberty, pregnancy and lactation, There is also a post-lactation phase involving considerable cell death and tissue re-modelling. The fact that many of these processes are post-natal makes them more amenable to manipulation and for this reason the mammary gland has been a very popular organ in which to study these processes.

\footnotetext{
Abbreviations used in this paper: CCN, secreted cysteine-rich protein family; ECM, extracellular matrix; GAG, glycosaminoglycan; HSPG, heparan sulphate proteoglycan; HUVEC, human umbilical vein endothelial cell; IGFBP, IGF binding protein; TEB, terminal end bud; TIC, Twisted gastrulation, IGFBP and CGN families.
}

*Address correspondence to: David J Flint. University of Strathclyde, SIPBS Building, 161 Cathedral Street, Glasgow G4 0RE, UK.
Tel: +44-141-548-2693. Fax: +44-141-553-4124. e-mail: david.flint@ @trath.ac.uk - web: http://www.strath.ac.uk/sipbs 
Mammary glands are exocrine glands containing both tubular and alveolar structures. They are composed of three tissues: epithelial, or parenchymal tissue, adipose and connective tissue. Whilst certain aspects of the adipocyte and its role in mammary morphogenesis have been reported, the roles of both adipose tissue and connective tissue have been studied far less than the parenchymal aspects. However, this has begun to change as the active role of stroma in tissue development has been better recognised. The rat mammary gland epithelium comprises continuous, branching ducts leading from the nipple to smaller ductules that terminate in terminal end buds (TEBs), blunt end buds, or alveoli. Unique sets of cellular and molecular differentiation mechanisms occur during each stage of mammary gland development and involve hormones, growth factors and the extracellular matrix. The inner luminal or secretory cells are separated from the basement membrane by an outer myoepithelial layer. Myoepithelial cells secrete basement membrane that separates the epithelium from the stromal compartment. Agroup of acini arising from one terminal duct is known as a terminal duct lobular unit (TDLU) and is generally considered to be the functional unit of the mammary gland.

\section{Insulin-like growth factors play an important role in mammary gland development}

The IGFs were discovered on the basis of their ability to increase cartilage sulfation and to replace the "sulfation factor activity" of growth hormone $(\mathrm{GH})$. In fact, it seems that 2 major lactogenic hormones, Prolactin (PRL) and GH exert their actions on mammary gland function by influencing several components of the IGF axis. While PRL seems to act directly on mammary tissue, the effects of $\mathrm{GH}$ are generally thought to be indirect, involving stimulation of IGF-I production. For example, GH treatment increases serum concentrations of IGF-I, and the expression of hepatic and mammary IGF-I mRNA. During ductal branching and alveolar development, prolactin and growth hormone induce IGF-II mRNA which in turn induces insulin receptor substrate-1 (IRS-1) and IRS-2.

Although the actions of IGF-I are well understood, IGF-II receptor signaling in mammary gland development is still somewhat unclear. Exogenous IGFs are mitogens and survival factors for both normal and tumorigenic mammary epithelial cells in culture. Mitogenic effects of IGFs are predominantly mediated through the IGF-I receptor. However, type II IGF receptors and hybrid type I IGF/insulin receptors also exist. When implanted into mammary glands of rodents, IGF-I increases ductal growth and can synergize with oestrogen to promote terminal end bud (TEB) development and elongation of ducts in hypophysectomized-ovariectomized rats. Based on these observations it was proposed that IGF-I, produced in the stroma under the stimulus of $\mathrm{GH}$, synergizes with estrogen to act on the parenchymal tissues to promote TEB formation and ductal growth. In support of this, overexpression of IGF-I in transgenic mice results in premature alveolar development and similar results were obtained with IGF-II overexpression, using the mammary-specific promoter, $\beta$-lactoglobulin. Furthermore, over-expression of IGF-II led to mammary tumours following successive pregnancies.

The nature of mammary development means that there is also a huge loss of epithelial cells, with extensive proteolytic degradation and remodelling of the extracellular matrix, at the end of lactation. Cell loss occurs in the absence of classical inflammation through the process of programmed cell death or apoptosis. For apoptosis to occur, suppression of IGF-mediated cell survival appears to be required since overexpressing IGF-I in mice could delay involution. These results support the proposal that IGFs promote survival of mammary epithelial cells and additional evidence for a role for IGF in mammary epithelial proliferation comes from in vitro studies on isolated epithelial cells and in mammary gland organ culture. (Flint et al., 2008).

\section{IGFBP expression in the embryo}

All six IGFBPs are expressed in complex fashion early postimplantation and during subsequent embryonic development. Each of the IGFBPs displays its own expression pattern, both spatially and temporally as well as often being co-expressed. They are up-regulated during critical periods of tissue morphogenesis, for example in the liver (IGFBP-1), whereas IGFBP-2 and IGFBP-4 mRNAs and IGF-II expression are often related, suggesting that these IGFBPs may be important in modulating IGF-II action. IGFBP-3 and IGFBP-5 mRNAs (2 highly structurally-related IGFBPs) often co-localize. IGFBP-5 is expressed in sites of neural and muscle development, for example during differentiation of ectodermal (e.g. neural) and mesodermal (e.g. osteoblast and myoblast) lineages. IGF-mediated tissue remodeling or cell death in sites of apoptosis in the embryo may be influenced by IGFBP-5. IGFBP-6 mRNA is expressed ubiquitously from mid-gestation but at relatively low levels. The function of this binding protein remains the least understood. Studies of IGFBP protein, using immunocytochemistry, show considerable overlap with mRNA expression patterns, although IGFBPs are secreted molecules and, not surprisingly, are also found in locations distal to the site of production. Additional, indirect, evidence for a role of the IGFBPs in development comes from their chromosomal relationship with homeobox (Hox) genes which are well known for their important functions during embryonic development. Each of the human IGFBP genes is present in the same chromosomal regions as a Hox gene and this can most likely be explained by co-evolution from a single ancestral gene locus via chromosomal duplication and translocation (Allan et al., 2001, Flint et al., 2008).

Expression patterns of the IGFBPs of this nature suggest their importance in developmental processes but there is still a dearth of experimental evidence that offers causal evidence and which provides evidence of the mechanisms involved. This is even more acute for the mammary gland because of its relatively limited development at this stage. Consequently, the best hopes for understanding the role of the IGFBPs in mammary development lie in studying its extensive post-natal, cyclical development.

\section{IGFBP expression in postnatal mammary development}

Distinct mRNA expression patterns of the IGFBPs in the mammary gland also occur during puberty and pregnancy, both with respect to their temporal patterns and localization within epithelial and stromal compartments. Progress is hampered by the fact that there are also species differences (Flint et al., 2000). Rodents have been most extensively studied in vivo with comprehensive descriptions of changes in IGFBP expression in the mouse mammary gland (Wood et al., 2000). The most abundant of the IGFBPs (protein and $\mathrm{mRNA}$ ) is IGFBP-5 which was highly expressed in the 
epithelium throughout postnatal growth, although mRNA was also evident occasionally in the stroma. IGFBP-3 was also expressed in both epithelium and stroma, being present in the outer epithelial cells of the TEB consistent with expression in cap cells, whereas IGFBP-5 mRNA was observed in the centre of the TEB, where cell death occurs to allow lumen formation. These findings are consistent with an apoptotic role for IGFBP-5. This apoptotic role for IGFBP-5 has also been proposed in in vitro studies of bovine mammosphere cultures where lumen formation was preceded by an increase in IGFBP-5 secretion. This appears to be too simplistic a notion however, since IGFBP-5 is also highly expressed in the developing ductal epithelium during puberty and pregnancy. IGFBP-3 localizes to the outer layer of ductal epithelial cells. In contrast, IGFBP-2 and -4 mRNA are predominantly expressed in the stroma, and IGFBP-2 expression correlates with macrophages proximal to TEBs. Intriguingly, expression of IGFBP-4 was consistent with a role in maintaining tissue boundaries, a process which may be of relevance to the disruption of boundaries which occurs during metastasis.

IGFBP levels in the mammary gland decreased during lactation, with the exception of IGFBP-3.

This suggests that IGFBPs may be decreased to allow the sensitivity to IGFs to be maintained as high as possible, in order to ensure cell survival, and optimum milk production, at this critical period for the neonate (Flint et al., 2008).

When the mammary gland ceases to produce milk it undergoes considerable cell death in which the gland returns to a state resembling the non-pregnant gland. During this process, in rats, there were increases in IGFBP-2 mRNA (4-fold), IGFBP-4 (6-fold) and a dramatic increase in both IGFBP- 5 mRNA and protein levels (50-fold), within $2 d$ of the cessation of the suckling stimulus. The increase in IGFBP-5 also occurs in mice, in pigs and in the dairy cow. Thus, during apoptosis in the mammary gland, there appears to be a general increase in IGFBP expression, although IGFBP-5 is quantitatively the most significant, reaching concentrations of $50-100 u g / m l$ in the involuting mammary gland. The most obvious explanation would be that the increase in IGFBPs serve to prevent the survival effects of IGFs, consistent with a role of IGFBPs as inhibitors of IGF actions (Flint et al., 2005, Flint et al., 2008).

\section{IGFBP production: is local or systemic the most im- portant?}

The source of IGFBPs in the mammary gland is uncertain, except for IGFBP-5, where it was virtually undetectable in serum (strongly implying that its local production is essential) and for IGFBP-1, where the converse may be true. However, mammary expression and serum concentrations of IGFBP-1 were inversely related, suggesting that locally produced IGFBP-1 may still be the major determinant of mammary concentrations, or may have additional, or specific roles from IGFBP-1 derived from the serum (Wood et al., 2000).

\section{What is the biological role of IGFBPs in the mammary gland?}

Evidence that IGFBPs play a role in inhibiting IGF actions in the mammary gland during lactation and post-lactation originated from indirect evidence where, for example, $\mathrm{GH}$ and prolactin, act together to optimise IGF-I synthesis (by $\mathrm{GH}$ ) whilst inhibiting IGFBP-5 production (by prolactin) (Flint et al., 2008)) (Flint et al., 2000). Prolactin also increases IGF-II production in the mammary gland and mammary IGFBP- 5 mRNA expression is decreased in CAATT-enhancer binding protein- $\beta$ _ko mice, which exhibit increased expression of the prolactin receptor. Although this suggests a mechanism which would maximise IGF effects, no causal relationship had been demonstrated. Direct evidence did, however, come from studies in which exogenous IGFBP-5 or IGFBP-3 inhibited IGF-I-mediated survival of mammary epithelial cells, with increased apoptosis and decreased phosphorylation of Akt and the forkhead transcription factor, FKHRL1. Consistent with the dramatic increases in IGFBP-5 expression in the involuting mammary gland, in vivo administration of IGFBP-5 during late pregnancy impaired mammary development and reduced invasion into the mammary fat pad. Studies in transgenic mice expressing IGFBP-5 in the mammary gland showed that IGFBP-5 led to decreased DNA content in the mammary gland, increased activity of the pro-apoptotic molecule caspase-3 and increased activity of plasmin along with decreased concentrations of two pro-survival molecules, Bcl-2 and Bcl-xL. These changes are all consistent with a pro-apoptotic effect of IGFBP-5. Whether this action of IGFBP-5 is due to inhibition of IGF action or some IGF-independent action is not clear from this study but involution is inhibited in transgenic mice over-expressing IGF-I and in transgenic mice overexpressing IGFBP-5, treatment with an IGF-analogue which binds weakly to IGFBP-5 partially overcame the effects of IGFBP-5 suggesting that IGFBP-5 was acting, at least in part, by inhibiting IGF action. Subsequently, it was shown that Igfbp5 null mice exhibit delayed mammary apoptosis adding yet more support for an apoptotic role of IGFBP-5. Despite the absence of any direct evidence for a role of IGFBPs other than IGFBP-5 in mammary gland function, the specific expression patterns of the IGFBPs, and the circumstantial evidence for their roles in developmental processes in general, make it likely that the other IGFBPs do play specific roles in mammary development and remodelling.

\section{IGFBPs and stroma}

Although much of the attention on IGFBPs has focussed on the parenchymal tissue, the role of IGFBPs in the stroma is attracting increasing attention, principally due to 2 lines of research. The first relates to the adipocyte which plays an important role in stromal instruction of parenchymal development. For a review of IGFBPs in adipose tissue see Baxter and Twigg (2009). In brief, adipose tissue secretes at least IGFBPs1-5 and, in the case of IGFBP-5, levels of expression can be very high. Whilst all of the IGFBPs can theoretically inhibit the actions of IGF-I (a major stimulus to adipocyte differentiation) IGFBP-3 has been shown to be a major inhibitor of adipocyte differentiation via an IGF-independent manner and may act in concert with TGF $\beta 1$ and connective tissue growth factor (CTGF). This action may be a critical part of the restriction of adipocyte differentiation in the mammary gland, which is evident during lactation, perhaps to preclude competition for nutrients when demand is high for the synthesis of lactose from glucose and fatty acids required for milk lipid synthesis. The second series of studies of relevance to IGFBPs in the stroma comes from recent publications which have linked insulin-like growth factor binding protein-5 (IGFBP-5) to metastasis and fibrotic disorders, including 
scleroderma and idiopathic pulmonary fibrosis. Increased IGFBP-5 expression is associated with poor outcome during mammary metastasis (Huynh, 1998, McGuire et al., 1994, Mita et al., 2007, Pekonen et al., 1992). IGFBP-5 also stimulates lung, dermal and hepatic fibroblasts, inducing fibrotic responses similar to those of TGF $\beta 1$ (Pilewski et al., 2005, Yasuoka et al., 2009a, Yasuoka et al., 2006a, Yasuoka et al., 2009b, Yasuoka et al., 2006b).This was somewhat surprising given that, at high concentrations, IGFBP-5 is apoptotic in mammary epithelial cells in vitro and in vivo (Marshman et al., 2003, Tonner et al., 2002) and is the IGFBP which increases dramatically during involution of the mammary gland (Clarkson and Watson, 2003, Stein et al., 2004) Consistent with an apoptotic function, two recent studies have shown that decreased expression of IGFBP-5 is associated with increased tumourigenesis in osteosarcoma (Su et al., 2011) and in breast cancer induced by foetal alcohol exposure (Polanco et al., 2010). However, it is possible to reconcile these apparent contradictory results by considering other aspects of the actions of IGFBPs. For example, at high concentrations IGFBPs inhibit the actions of IGFs whereas at lower, typically equimolar concentrations they can enhance IGF actions. Since they are secreted proteins, there is the potential to produce a gradient of IGFBP concentration in which the highest producing cells undergo apoptosis but neighbouring cells (where IGFBP concentrations are lower) may survive and even have their survival enhanced by IGFs. We have recently shown that IGFBP-5 can indeed enhance survival of epithelial cells and does so by enhancing their adhesion to the substratum (Allan et al., 2008) (Fig. 1). Whilst enhancing their adhesion to the substratum, IGFBP-5 also maintains E-cadherin expression and
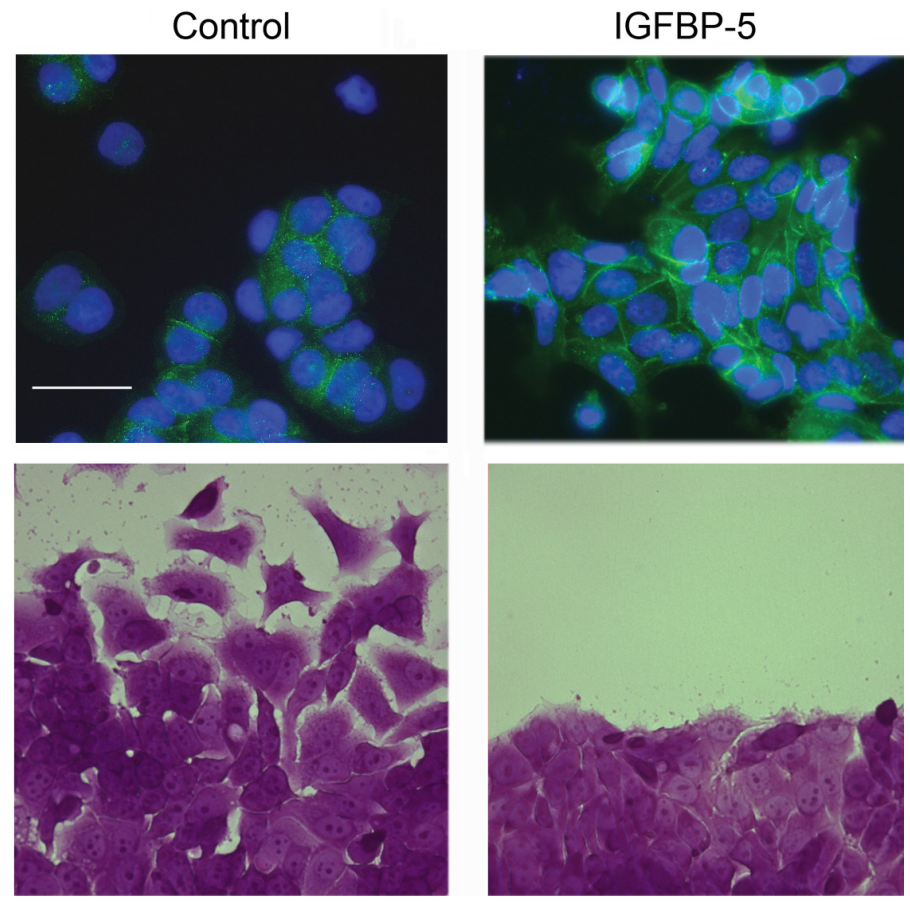

Fig. 1. IGFBP-5 increases adhesion but decreases migration. (Upper panel) MCF-7 cells form spheroids, with limited adhesion to the substratum, in serum-free conditions. IGFBP-5 induces epithelial cell adhesion and spreading, whilst maintaining E-cadherin expression (green). Nuclei are stained with DAPI (blue). (Lower panel) In the presence of serum, MCF-7 cells migrate from the wound edge. IGFBP-5 potently inhibits this migration. inhibits epithelial migration. This may be part of a repair mechanism in which neighbouring cells maintain epithelial integrity (barrier function, electrical resistance) whilst in the process of removing apoptotic cells. If IGFBP-5 does serve such a protective role for the epithelium, why would it activate fibroblasts with the potential to disrupt epithelial function via fibrotic scarring? Again, these apparently contradictory findings may be reconciled by proposing that, upon injury, IGFBP-5 stimulates a mesenchymal response (fibrosis) to effect a rapid repair, whilst simultaneously enhancing epithelial survival and spreading, in order to limit the fibrotic response to the mesenchymal compartment. Even though we have shown that IGFBP-5 does act upon fibroblasts, its actions are phenotypically very distinct from those of TGF $\beta 1$ (Fig. 2). Whereas TGF $\beta 1$ induces alignment and organisation of fibroblasts into a swirling pattern, IGFBP-5 induces these cells to migrate into groups in which adhesion to the substratum appears to be decreased. Understanding the precise mechanism of action of IGFBP-5 on fibroblasts will be required, to better understand its precise role. Activation of the mesenchymal compartment, whilst maintaining the epithelial-mesenchymal boundary could be an important part of the tissue remodelling which happens at the end of lactation. Thus, even though matrix metalloprotease expression increases and much cell death occurs (Clarkson and Watson, 2003, Stein et al., 2004, Tonner etal., 1997) some ductal cells survive, surrounded by a fibrotic response from the mesenchymal cells (O'Brien et al., 2010). This remodelling is delayed in an IGFBP-5 ko mouse (Ning et al., 2007). This encapsulation process could ensure that residual ductal epithelium does not become excessively disrupted by the fibrotic response, thereby enhancing the prospects of a successful re-development of the gland in subsequent pregnancies (O'Brien et al., 2010). The host response to tumours, where unaffected tissue proximal to the tumour expresses a wound-healing signature, including increased collagen and fibronectin expression and increased expression of IGFBP-5 (Akkiprik et al., 2008) may well be analogous to this response. Thus, the association between IGFBP-5 and metastasis (Huynh, 1998, McGuire et al., 1994, Mita et al., 2007, Pekonen et al., 1992) may be a host response designed to limit, rather than promote, metastasis. We have evidence to support this from co-culture experiments in which IGFBP-5 can limit fibroblast invasion of epithelial monolayers (Fig. 3) and antagonise the actions of TGF $\beta 1$. Furthermore, IGFBP- 5 is one of the major secreted products of the Senescence Messaging Secretome (SMS) now thought to be a tumour suppressor response (Adams, 2009) and this would be consistent with the tumour suppressor role demonstrated for IGFBP-5 (Polanco et al., 2010, Su et al., 2011).

\section{Demonstrating causality in IGFBP function}

Our understanding of the actions and roles of the IGFBPs is still in its early stages. The degree of redundancy or non-essential functions of IGFBPs has not aided the process of attributing physiological relevance to many studies which describe mechanistic actions of the IGFBPs. Some of the approaches currently used, and of potential value in understanding the actions of IGFBPs in the mammary gland, are described below.

\section{i) IGFBP deficiency}

Knockouts of IGFBP-1 to -6 have been reported, and these are, surprisingly, essentially phenotypically normal, even when 


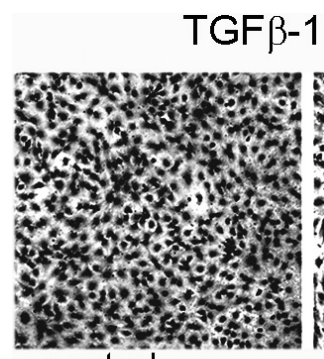

control

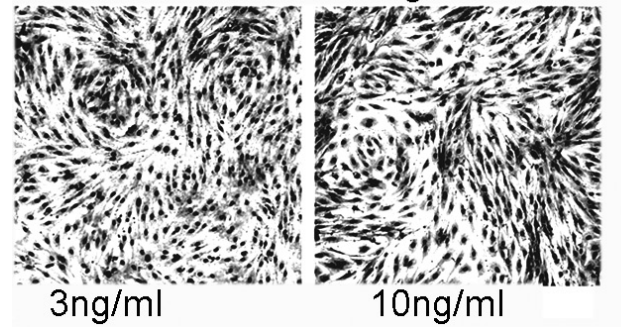

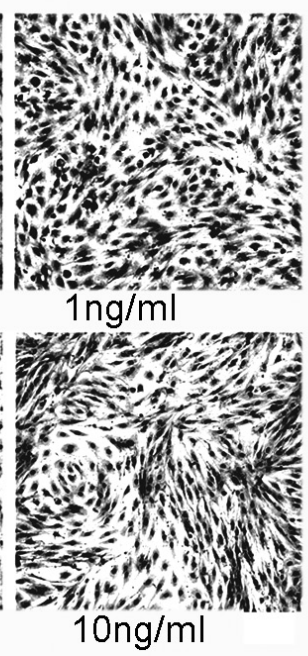

IGFBP-5
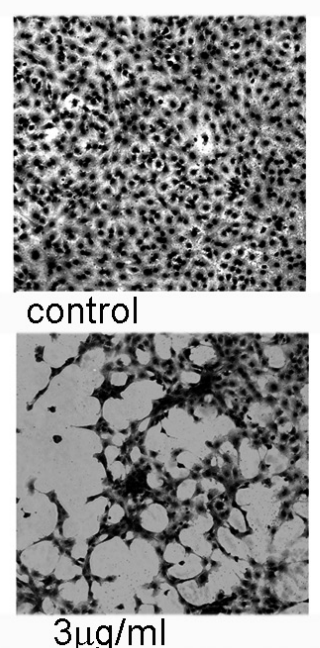

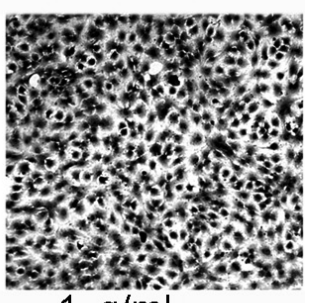

$1 \mu \mathrm{g} / \mathrm{ml}$

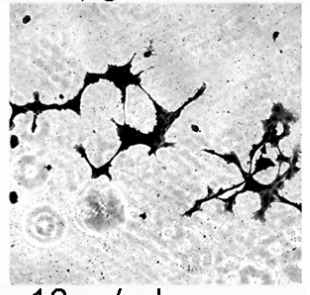

$10 \mu \mathrm{g} / \mathrm{ml}$

Fig. 2.TGF $\beta 1$ induces fibroblast activation whereas IGFBP-5 induces de-adhesion. TGF $\beta 1$ induces a dose-dependent phenotypic response in fibroblasts with a characteristic alignment and swirling pattern. IGFBP-5, in contrast, induces cells to migrate into small groups with decreased cell-substratum adhesion.

more than one IGFBP has been knocked out. This suggests redundancy within the IGFBPs. Nevertheless, specific phenotypes do exist including Igfbp5 null mice which have delayed mammary apoptosis, consistent with an apoptotic role for IGFBP-5, and mild glucose intolerance and increased adiposity. Igfbp 4 null mice which exhibit growth inhibition and Igfbp 1 null mice which have abnormal hepatic repair. igfbp-2null mice have a bone phenotype which may be the result of both IGF-dependent and IGF-independent actions (Flint et al., 2008).

\section{ii) IGFBP treatment}

Genetically modified mice overexpressing specific IGFBPs have been described (Silha and Murphy, 2002, Wolf et al., 2005). IGFBP-1 overexpression leads to metabolic defects consistent with its proposed role in glucose uptake, resulting in hepatic insulin resistance (Rajkumar et al., 1995, Rajkumar and Murphy, 1999). and some growth retardation (Gay et al., 1997). Igfbp2 overexpression also produces a modest reduction in body weight (Hoeflich et al., 2000). Intriguingly a growth retardation is also evident in Igfbp3 transgenic mice but this is not evident if the IGFBP-3 is mutated to inhibit binding of IGF-I (Silha et al., 2005, Silha et al., 2006). This demonstrates that IGFBPs can serve as inhibitors of IGFs in vivo. A protease-resistant form of IGFBP-4 decreased weight of smooth muscle-containing tissues, (Zhang et al., 2002) whilst mice overexpressing Igfbp4in lymphoid tissue exhibited decreased may simply reflect the fact that overexpression is a rather blunt tool and that, if IGFBPs are produced in excessive amounts, then the models will largely reflect phenotypes which can be explained by inhibition of IGF action. Determining the actions of the IGFBPs at physiological concentrations thus remains a significant challenge/ barrier to our understanding of their roles in vivo.

\section{Mechanisms of action of IGFBPs}

\section{i) Influencing the actions of IGFs}

The best studied action of the IGFBPs is binding to IGFs. However, some debate exists about their effects upon binding IGFs. IGFBPs may inhibit IGF action by preventing binding to IGF receptors or, when bound to the extracellular matrix, they may serve as a delivery "reservoir", enhancing IGF actions. At least four of the IGFBPs bind to the surface of cells or the extracellular matrix involving RGD sequences and heparin binding domains. IGFBP-3 and IGFBP-5 also bind to type I collagen, vitronectin and fibronectin (Pilewski et al., 2005). IGFBPs once secreted are vulnerable to proteolytic cleavage and are degraded by several proteases whereas IGFBP binding to the ECM can protect IGFBPs from proteolytic degradation, potentially prolonging their bioavailability. IGFBP binding to extracellular matrix or to the cell surface is also influenced by phosphorylation status or proteolytic cleavage. For a review of these actions see (Beattie et al., 2006). All of
Day 1 control

Fig. 3. Co-culture of epithelial cells (stained red for E-cadherin) with fibroblasts (stained green for collagen). The formation of a boundary is evident after 1 day. After 3 days, the fibroblasts migrate beyond the boundary, but this is inhibited by IGFBP-5.

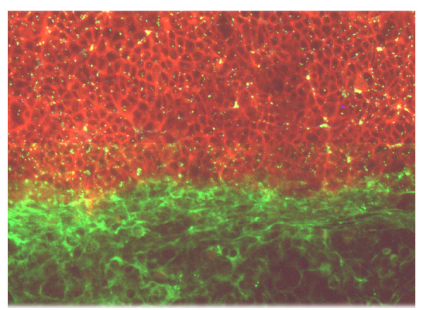

Day 3

control

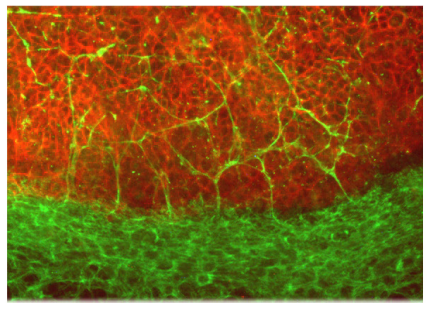

IGFBP-5

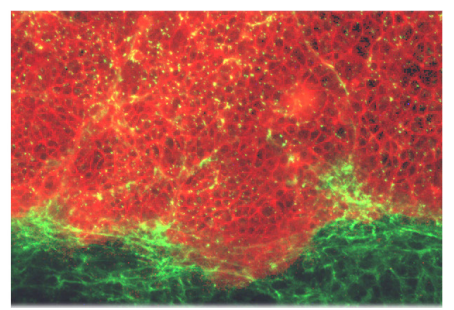


these changes in IGFBP structure could enhance IGF actions by increasing IGF bioavailability, in vivo.

\section{ii) Direct effects of IGFBPs}

Cell surface "receptors" have been proposed for IGFBP-3 and IGFBP-5, although these studies remain to be confirmed. IGFindependent actions have been proposed for IGFBP-3 in mammary epithelial cells. IGFBP-3 has anti-proliferative effects on mammary epithelial cells and is induced by members of the TGF- $\beta$ family including TGF- $\beta 1$ in breast cancer cells. IGFBP-3 binds with high affinity to the type $V$ TGF- $\beta$ receptor suggesting the possibility that induction of IGFBP-3 synthesis by TGF- $\beta 1$ may be a positive loop to further inhibit growth of mammary epithelium. Perhaps the strongest support for a mechanism of action independent of IGF-I comes from studies in which, despite their sequence similarity, actions of IGFBP-3 and -5 on cell survival are often opposite. This would not be anticipated if they were both acting by inhibiting the actions of IGFs. ERK activation by IGFBP-5 has been described and p38MAPK-dependent actions of IGFBP-5 and the ability of IGFBP-5 to activate p44/p42MAPK (Yasuoka et al., 2009b) have also been reported. It is also still a matter of debate as to whether IGFBPs exert intracellular actions, including within the nucleus. Novel uptake pathways by cells have been shown for IGFBP-3, mediated by $\mathrm{C}$-terminal basic residues, involving caveolin and transferrin receptors. A more detailed examination of intracellular effects is needed to clarify their physiological relevance (Beattie et al., 2006).

In addition to their proposed direct actions upon cells, IGFBPs also exhibit extracellular interactions not involving the sequestration of IGFs. For example, plasminogen is inappropriately activated during mammary gland development in IGFBP-5 transgenic mice (Tonner et al., 2002) and this was confirmed in vitro, where IGFBP-5 was shown to directly activate tPA but not uPA (Sorrell et al., 2006). Several members of the secreted cysteine-rich (CCN) protein family, which includes connective tissue growth factor (CTGF), CYR61 and Nov were re-named IGFBP8-10 because of structural similarities. The CCN family possess integrin "receptors" and are considered to exert their effects extracellularly by interaction with integrins, the ECM and growth factors. For example CTGF binds to VEGF (Inoki et al., 2002) and inhibits its actions, whereas it binds to, and enhances the actions of, TGF $\beta 1$ (Abreu et al., 2002). We believe that, at least for IGFBP-5, it may be more appropriate to consider it as a member of the CCN family as it possesses growth factor and integrin binding properties, as well as interacting, via its heparin-binding domain, with a variety of extracellular matrix molecules. This, in turn, suggests that IGFBPs may act indirectly, extracellularly, in a fashion similar to that of CTGF. CTGF acts downstream of TGF- $\beta 1$ (Nguyen and Goldschmeding, 2008) and IGFBP-3 is a downstream target of TGF- $\beta 1$ and binds to the typeV TGF $\beta$ receptor. TGF- $\beta 1$ activates ADAM-12 which proteolytically cleaves IGFBP-5. These findings link the IGFBPs with TGF- $\beta 1$, a known inhibitor of epithelial cell proliferation and activator of mesenchymal cells. Beyond this linkage, the CCN family and the IGFBPs have been included in a larger family of secreted cysteine-rich proteins, termed TIC, that comprises the Twisted gastrulation (TSG), IGFBP and CCN families (Pell et al., 2005). All contain a characteristic conserved $5{ }^{\prime}{ }^{N}$-terminal domain, a non-conserved linker region and a 3 ' cysteine-rich domain. The TSG and CCN families have major roles in development. For example, TSG is involved in patterning in the fly embryo whereas the CCN family has actions which include differentiation, adhesion, and migration. The fact that the TSG and $\mathrm{CCN}$ proteins have significant functions in development, adds further support to the proposal that the IGFBPs have evolved to serve a similar role. IGFBPs are primitive molecules, found in all vertebrates studied so far and an IGFBP-related protein in Drosophila has been described (Alic and Partridge, 2008, Honegger et al., 2008).

\section{iii) IGFBP proteolysis}

Considerable interest in IGFBP proteolysis was evident around 10 years ago. However, the difficulties in assigning physiological significance to these studies has led to a much reduced effort in this area. The first reports of IGFBP proteolysis were in late human pregnancy serum, directed against IGFBP-3 subsequently demonstrated in pregnant mouse and rat serum, in human amniotic fluid and in seminal plasma. Certain proteinases (e.g. MMPs and PAPP-A) appear to degrade IGFBP-IGF complexes, probably near the cell surface, releasing intact, biologically active IGFs able to bind to their receptors on the cell surface (Beattie et al., 2006) and interest in these proteases continues (Conover et al., 2010). This may represent homeostatic conditions but could become more significant if IGFBP-degrading proteinases become more active (such as MMPs in tumour growth). Other IGFBP-degrading proteinases, such as cathepsins, may serve a role of inactivation of IGFs and IGFBPs in the extracellular environment. It has also been proposed that IGFBP proteases could also have important actions by producing novel, bioactive fragments.

Finally, the ability of the IGFBPs to influence IGF action can also be modified by IGF proteases, producing amino-terminally shortened forms of IGF-I, such as des(1-3) IGF-I, which have weak affinity towards IGFBPs. Such truncated IGF-I forms show increased biological activity but whether this process has major physiological significance still needs to be demonstrated (Beattie et al., 2006).

\section{Conclusions}

IGFBP expression in the mammary gland is complex, tissue-and stage-specific. However, their expression in the embryo and their chromosal linkage to Hox genes makes it tempting to speculate that they play important developmental roles in the mammary gland. The fact that IGFs do, indeed, play critical roles in mammary development, and the fact that the IGFBPs can clearly influence IGF actions, adds further weight to this proposal. Indeed, their ability to bind to IGFs has been the main focus of attention in terms of understanding their mechanism of action. Transgenic models involving over-expression of IGFBPs supports this role and suggest predominantly inhibitory effects of IGFBPs on IGF actions. In vivo studies, achieving physiological concentrations of IGFBPs, are, however, required before firm conclusions can be made about their roles in distinct physiological processes. Such an inhibitory role is surely not the explanation for the presence of high concentrations of the IGFBPs in the circulation, where they would more likely be considered as a latent store of IGFs. In addition, the activation of pregnancy-associated proteases in serum, perhaps to allow greater delivery of IGFs, adds further, albeit circumstantial, 
evidence to support this proposal.

The enhancing effects of IGFBPs are typically demonstrated when IGFs and IGFBPs are in approximately equimolar concentrations and, although these effects have been consistently demonstrated, their physiological relevance still remains uncertain. In such studies, IGFBPs may artefactually increase the half-life of IGFs by preventing their degradation in the culture medium or their adsorption to plastic. On the other hand, in support of such enhancing actions, IGFBPs also bind to the ECM, involving their RGD sequences or heparin-binding domains, and this can lead to a reduction in the affinity of IGFBPs for IGFs. Such a role would be consistent with increased bioavailability of IGFs and thereby enhanced IGF action. However, studies utilising more physiological conditions, perhaps involving perfusion, to simulate the kinetics of clearance in the extracellular environment, will be required to provide more compelling evidence. In this respect, comparatively little is known about tissue clearance and pericellular concentrations of IGFBPs, although there are some reports (Xu et al., 1996, $\mathrm{Xu}$ et al., 1997). The secretion of IGFBPs into the extracellular environment might also serve as a barrier to limit access of IGFs to cellular receptors, and such a proposal has been made for the mammary gland for IGFBP-4 (Allar and Wood, 2004) and IGFBP-5 (Flint et al., 2000).

Mammary development is a complex process involving several major cell types and with specific requirements for proliferation and apoptosis in different cellular compartments (Wood et al., 2000). Recognition of this compartmentalisation of the gland and the expression patterns of the IGFBPs is crucial if we are to understand their precise functions in the mammary gland.

It is now evident that IGFBPs can act independently of the IGFs but their relevance/importance in vivo has also been difficult to demonstrate. The absence of major phenotypes in mice, even when several IGFBPs had been deleted, suggests a degree of redundancy of their actions, although there have been no reports of compensatory increases in the secretion of other IGFBPs to explain this. Nevertheless, IGFBP knockoutmice are now beginning to identify tissue-specific phenotypes (DeMambro et al., 2008, Leu et al., 2003, Ning et al., 2007). Additional studies, involving the use of conditional knockouts, and the use of the cleared mammary fat pad technique using tissue from knockout animals should improve our understanding of their roles in vivo. This has already been successfully developed for IGF-I, where deletion of either IGF-I or the IGF-IR are lethal or result in animals that are reproductively compromised. Transplantation of prenatal mammary epithelium from the IGF-IR null mouse into cleared fat pads of wild-type mice has also been used to identify an important role for IGFs in mammary development (Hadsell and Bonnette, 2000) and, in animals with an IGF-I deletion, post-natal survivors exhibited impaired mammary ductal growth (Kleinberg et al., 2000).

For the moment it seems that our understanding of the in vivo role of these proteins will continue to depend upon circumstantial evidence. Demonstrating a role for IGFBPs in mammary gland development requires that the effective IGFBP concentration changes during a particular process (eg apoptosis) and that increasing the concentration of IGFBP by transgenesis (within physiological limits) or knockdown of the gene, influences the process in a predictable fashion. To date, for the mammary gland, this has only been achieved for IGFBP-5, strongly implicating it in apoptotic events associated with involution.
More recently it has become evident that the IGFBPs can act independently of the IGF axis. The structural similarities of the IGFBPs with other secreted cysteine-rich proteins, which do not bind IGFs, supports the concept that IGFBPs have IGF-independent actions. Many of the CCN proteins, for example, influence various growth factor actions extracellularly without utilising specific receptors of their own. The CCNs were re-named as IGFBPs but it may be more appropriate to consider the IGFBPs to be part of the CCN family. If so, the complexity of the extracellular environment will provide a significant challenge to reductionist approaches designed to understand the mechanisms of action of the larger TIC family to which the IGFBPs belong.

IGFBPs undoubtedly play important roles in the development of the mammary gland, based upon their expression patterns and the transgenic and knockout animal models, although functional evidence is strongest for IGFBP-5 and IGFBP-3. A better understanding of the mechanisms of action of IGFBPs is required to provide a better assessment of their potential to influence mammary development. Perhaps the close similarities of the IGFBPs with the CCN and TSG families, which definitely have important developmental roles, will mean that an understanding of one family will provide clues as to the role of the others, particularly with respect to the mechanisms involved in the IGF-independent actions of the IGFBPs. The IGFBPs may ultimately prove to be of much greater significance because of their IGF-independent actions, rather than via the specific action which led to their name.

\section{Acknowledgements}

We would like to thank the BBSRC for their support of our research programme. We would also like to thanks Mr Deborshi Guha, Mrs Ibtisam Kaziri and Mr Ameer Fasal for their technical contributions.

\section{References}

ABREU, J.G., KETPURA, N.I., REVERSADE, B. and DE ROBERTIS, E.M. (2002). Connective-tissue growth factor (CTGF) modulates cell signalling by BMP and TGF-beta. Nat Cell Biol 4: 599-604.

ADAMS, P.D. (2009). Healing and hurting: molecular mechanisms, functions, and pathologies of cellular senescence. Mol Cell 36: 2-14.

AKKIPRIK, M., FENG, Y., WANG, H., CHEN, K., HU, L., SAHIN, A., KRISHNAMURTHY, S., OZER, A., HAO, X. and ZHANG, W. (2008). Multifunctional roles of insulin-like growth factor binding protein 5 in breast cancer. Breast Cancer Res 10:212-225.

ALIC, N. and PARTRIDGE, L. (2008). Stage debut for the elusive Drosophila insulinlike growth factor binding protein. J Biol 7: 18.

ALLAN, G.J., BEATTIE, J. and FLINT, D.J. (2008). Epithelial injury induces an innate repair mechanism linked to cellular senescence and fibrosis involving IGF-binding protein-5. J Endocrinol 199: 155-164.

ALLAN, G.J., FLINT, D.J. and PATEL, K. (2001). Insulin-like growth factor axis during embryonic development. Reproduction 122: 31-39.

ALLAR, M.A. and WOOD, T.L. (2004). Expression of the Insulin-Like Growth Factor Binding Proteins during Postnatal Development of the Murine Mammary Gland. Endocrinology 145: 2467-2477.

ARAI, T., PARKER, A., BUSBY, W., JR. and CLEMMONS, D.R. (1994). Heparin, heparan sulfate, and dermatan sulfate regulate formation of the insulin-like growth factor-I and insulin-like growth factor-binding protein complexes. J Biol Chem 269: 20388-20393.

BAXTER, R.C. and TWIGG, S.M. (2009). Actions of IGF binding proteins and related proteins in adipose tissue. Trends Endocrinol Metab 20: 499-505.

BEATTIE, J., ALLAN, G.J., LOCHRIE, J.D. and FLINT, D.J. (2006). Insulin-like growth factor-binding protein-5 (IGFBP-5): a critical member of the IGF axis. Biochem J 395: 1-19.

BIENVENU, G., SEURIN, D., GRELliER, P., FROMENT, P., BAUDRIMONT, M., 
MONGET, P., LE BOUC, Y. and BABAJKO, S. (2004). Insulin-like growth factor binding protein- 6 transgenic mice: postnatal growth, brain development, and reproduction abnormalities. Endocrinology 145: 2412-2420.

CLARKSON, R.W. and WATSON, C.J. (2003). Microarray analysis of the involution switch. J Mammary Gland Biol Neoplasia 8: 309-319.

CONOVER, C.A., BALE, L.K., MADER, J.R., MASON, M.A., KEENAN, K.P. and MARLER, R.J. (2010). Longevity and age-related pathology of mice deficient in pregnancy-associated plasma protein-A. J GerontolABiol Sci Med Sci65:590-599.

DEMAMBRO, V.E., CLEMMONS, D.R., HORTON, L.G., BOUXSEIN, M.L., WOOD, T.L., BEAMER, W.G., CANALIS, E. and ROSEN, C.J. (2008). Gender-specific changes in bone turnover and skeletal architecture in igfbp-2-null mice. Endocrinology 149: 2051-2061.

FLINT, D.J., BOUTINAUD, M., TONNER, E., WILDE, C.J., HURLEY, W., ACCORSI, P.A., KOLB, A.F., WHITELAW, C.B., BEATTIE, J. and ALLAN, G.J. (2005). Insulin-like growth factor binding proteins initiate cell death and extracellular matrix remodeling in the mammary gland. Domest Anim Endocrinol 29: 274-282.

FLINT, D.J., TONNER, E. and ALLAN, G.J. (2000). Insulin-like growth factor binding proteins: IGF-dependent and -independent effects in the mammary gland. $J$ Mammary Gland Biol Neoplasia 5: 65-73.

FLINT, D.J., TONNER, E., BEATTIE, J. and ALLAN, G.J. (2008). Role of insulin-like growth factor binding proteins in mammary gland development. J Mammary Gland Biol Neoplasia 13: 443-453.

GAY, E., SEURIN, D., BABAJKO, S., DOUBLIER, S., CAZILLIS, M. and BINOUX, M. (1997). Liver-specific expression of human insulin-like growth factor binding protein-1 in transgenic mice: repercussions on reproduction, ante- and perinatal mortality and postnatal growth. Endocrinology 138: 2937-4297.

HADSELL, D.L. and BONNETTE, S.G. (2000). IGF and insulin action in the mammary gland: lessons from transgenic and knockout models. J Mammary Gland Biol Neoplasia 5: 19-30.

HOEFLICH, A., FETTSCHER, O., LAHM, H., BLUM, W.F., KOLB, H.J., ENGELHARDT, D., WOLF, E. and WEBER, M.M. (2000). Overexpression of insulin-like growth factor-binding protein-2 results in increased tumorigenic potential in $\mathrm{Y}-1$ adrenocortical tumor cells. Cancer Res 60: 834-838.

HONEGGER, B., GALIC, M., KOHLER, K., WITTWER, F., BROGIOLO, W., HAFEN, E. and STOCKER, H. (2008). Imp-L2, a putative homolog of vertebrate IGFbinding protein 7, counteracts insulin signaling in Drosophila and is essential for starvation resistance. J Biol 7: 10.

HUYNH, H. (1998). In vivo regulation of the insulin-like growth factor system of mitogens by human chorionic gonadotropin. Int $J$ Oncol 13: 571-575.

INOKI, I., SHIOMI, T., HASHIMOTO, G., ENOMOTO, H., NAKAMURA, H., MAKINO, K., IKEDA, E., TAKATA, S., KOBAYASHI, K. and OKADA, Y. (2002). Connective tissue growth factor binds vascular endothelial growth factor (VEGF) and inhibits VEGF-induced angiogenesis. FASEB J 16: 219-221.

KLEINBERG, D.L., FELDMAN, M. and RUAN, W. (2000). IGF-I: an essential factor in terminal end bud formation and ductal morphogenesis. J Mammary Gland Biol Neoplasia 5: 7-17.

LEU, J.I., CRISSEY, M.A., CRAIG, L.E. and TAUB, R. (2003). Impaired hepatocyte DNA synthetic response posthepatectomy in insulin-like growth factor binding protein 1-deficient mice with defects in C/EBP beta and mitogen-activated protein kinase/extracellular signal-regulated kinase regulation. MolCellBiol23: 1251-1259.

MARSHMAN, E., GREEN, K.A., FLINT, D.J., WHITE, A., STREULI, C.H. and WESTWOOD, M. (2003). Insulin-like growth factor binding protein 5 and apoptosis in mammary epithelial cells. J Cell Sci 116: 675-682.

MCGUIRE, S.E., HILSENBECK, S.G., FIGUEROA, J.A., JACKSON, J.G. and YEE, D. (1994). Detection of insulin-like growth factor binding proteins (IGFBPs) by ligand blotting in breast cancer tissues. Cancer Lett 77: 25-32.

MITA, K., ZHANG, Z., ANDO, Y., TOYAMA, T., HAMAGUCHI, M., KOBAYASHI, S., HAYASHI, S., FUJII, Y., IWASE, H. and YAMASHITA, H. (2007). Prognostic significance of insulin-like growth factor binding protein (IGFBP)-4 and IGFBP-5 expression in breast cancer. Jpn J Clin Oncol 37: 575-582.

MOHAN, S., NAKAO, Y., HONDA, Y., LANDALE, E., LESER, U., DONY, C., LANG, K. and BAYLINK, D.J. (1995). Studies on the mechanisms by which insulin-like growth factor (IGF) binding protein-4 (IGFBP-4) and IGFBP-5 modulate IGF actions in bone cells. J Biol Chem 270: 20424-20431.

NGUYEN, T.Q. and GOLDSCHMEDING, R. (2008). Bone Morphogenetic Protein-7 and Connective Tissue Growth Factor: Novel Targets for Treatment of Renal
Fibrosis? Pharm Res. 25: 2416-2426.

NING, Y., HOANG, B., SCHULLER, A.G., COMINSKI, T.P., HSU, M.S., WOOD, T.L. and PINTAR, J.E. (2007). Delayed mammary gland involution in mice with mutation of the insulin-like growth factor binding protein 5 gene. Endocrinology 148: 2138-2147.

O'BRIEN, J., LYONS, T., MONKS, J., LUCIA, M.S., WILSON, R.S., HINES, L., MAN, Y.G., BORGES, V. and SCHEDIN, P. (2010). Alternatively activated macrophages and collagen remodeling characterize the postpartum involuting mammary gland across species. Am J Pathol 176: 1241-1255.

PEKONEN, F., NYMAN, T., ILVESMAKI, V. and PARTANEN, S. (1992). Insulin-like growth factor binding proteins in human breast cancer tissue. Cancer Res 52: 5204-5207.

PELL, J.M., SALIH, D.A., COBB, L.J., TRIPATHI, G. and DROZD, A. (2005). The role of insulin-like growth factor binding proteins in development. Rev Endocr Metab Disord 6: 189-198.

PILEWSKI, J.M., LIU, L., HENRY, A.C., KNAUER, A.V. and FEGHALI-BOSTWICK, C.A. (2005). Insulin-like growth factor binding proteins 3 and 5 are overexpressed in idiopathic pulmonary fibrosis and contribute to extracellular matrix deposition. Am J Pathol 166: 399-407.

POLANCO, T.A., CRISMALE-GANN, C., REUHL, K.R., SARKAR, D.K. and COHICK, W.S. (2010). Fetal alcohol exposure increases mammary tumor susceptibility and alters tumor phenotype in rats. Alcohol Clin Exp Res 34: 1879-1887.

RAJKUMAR, K., BARRON, D., LEWITT, M.S. and MURPHY, L.J. (1995). Growth retardation and hyperglycemia in insulin-like growth factor binding protein-1 transgenic mice. Endocrinology 136: 4029-4034.

RAJKUMAR, K. and MURPHY, L.J. (1999). Enhanced gluconeogenesis and hepatic insulin resistance in insulin-like growth factor binding protein-1 transgenic mice. Biochim Biophys Acta 1426: 491-497.

SALIH, D.A., MOHAN, S., KASUKAWA, Y., TRIPATHI, G., LOVETT, F.A., ANDERSON, N.F., CARTER, E.J., WERGEDAL, J.E., BAYLINK, D.J. and PELL, J.M. (2005). Insulin-like growth factor-binding protein-5 induces a gender-related decrease in bone mineral density in transgenic mice. Endocrinology 146: 931-940.

SALIH, D.A., TRIPATHI, G., HOLDING, C., SZESTAK, T.A., GONZALEZ, M.I., CARTER, E.J., COBB, L.J., EISEMANN, J.E. and PELL, J.M. (2004). Insulin-like growth factor-binding protein 5 (Igfbp5) compromises survival, growth, muscle development, and fertility in mice. Proc Natl Acad Sci USA 101: 4314-4319.

SILHA, J.V., GUI, Y., MISHRA, S., LECKSTROM, A., COHEN, P. and MURPHY, L.J. (2005). Overexpression of gly56/gly80/gly81-mutant insulin-like growth factorbinding protein-3 in transgenic mice. Endocrinology 146: 1523-1531.

SILHA, J.V. and MURPHY, L.J. (2002). Insights from insulin-like growth factor binding protein transgenic mice. Endocrinology 143: 3711-3714.

SILHA, J.V., SHEPPARD, P.C., MISHRA, S., GUI, Y., SCHWARTZ, J., DODD, J.G. and MURPHY, L.J. (2006). Insulin-like growth factor (IGF) binding protein-3 attenuates prostate tumor growth by IGF-dependent and IGF-independent mechanisms. Endocrinology 147: 2112-2121.

SORRELL, A.M., SHAND, J.H., TONNER, E., GAMBERONI, M., ACCORSI, P.A., BEATTIE, J., ALLAN, G.J. and FLINT, D.J. (2006). Insulin-like growth factor-binding protein- 5 activates plasminogen by interaction with tissue plasminogen activator, independently of its ability to bind to plasminogen activator inhibitor-1, insulin-like growth factor-I, or heparin. J Biol Chem 281: 10883-10889.

STEIN, T., MORRIS, J.S., DAVIES, C.R., WEBER-HALL, S.J., DUFFY, M.A., HEATH, V.J., BELL, A.K., FERRIER, R.K., SANDILANDS, G.P. and GUSTERSON, B.A. (2004). Involution of the mouse mammary gland is associated with an immune cascade and an acute-phase response, involving LBP, CD14 and STAT3. Breast Cancer Res 6: R75-R91.

SU, Y., WAGNER, E.R., LUO, Q., HUANG, J., CHEN, L., HE, B.C., ZUO, G.W., SHI, Q., ZHANG, B.Q., ZHU, G. et al., (2011). Insulin-like growth factor binding protein 5 suppresses tumor growth and metastasis of human osteosarcoma. Oncogene. 30: 3907-3919.

TONNER, E., BARBER, M.C., ALLAN, G.J., BEATTIE, J., WEBSTER, J., WHITELAW, C.B. and FLINT, D.J. (2002). Insulin-like growth factor binding protein-5 (IGFBP-5) induces premature cell death in the mammary glands of transgenic mice. Development 129: 4547-4557.

TONNER, E., BARBER, M.C., TRAVERS, M.T., LOGAN, A. and FLINT, D.J. (1997). Hormonal control of insulin-like growth factor-binding protein-5 production in the involuting mammary gland of the rat. Endocrinology 138: 5101-5107. 
WOLF, E., SCHNEIDER, M.R., ZHOU, R., FISCH, T.M., HERBACH, N., DAHLHOFF, M., WANKE, R. and HOEFLICH, A. (2005). Functional consequences of IGFBP excess-lessons from transgenic mice. Pediatr Nephrol 20: 269-278.

WOOD, T.L., RICHERT, M.M., STULL, M.A. and ALLAR, M.A. (2000). The insulin-like growth factors (IGFs) and IGF binding proteins in postnatal development of murine mammary glands. J Mammary Gland Biol Neoplasia 5: 31-42.

XU, S., CWYFAN-HUGHES, S.C., VAN DER STAPPEN, J.W., SANSOM, J., BURTON, J.L., DONNELLY, M. and HOLLY, J.M. (1996). Altered insulin-like growth factor-II (IGF-II) level and IGF-binding protein-3 (IGFBP-3) protease activity in interstitial fluid taken from the skin lesion of psoriasis. J Invest Dermatol 106: 109-112.

XU, S., SAVAGE, P., BURTON, J.L., SANSOM, J. and HOLLY, J.M. (1997). Proteolysis of insulin-like growth factor-binding protein-3 by human skin keratinocytes in culture in comparison to that in skin interstitial fluid: the role and regulation of components of the plasmin system. J Clin Endocrinol Metab 82: 1863-1868.

YASUOKA, H., HSU, E., RUIZ, X.D., STEINMAN, R.A., CHOI, A.M. and FEGHALIBOSTWICK, C.A. (2009a). The fibrotic phenotype induced by IGFBP-5 is regulated by MAPK activation and egr-1-dependent and -independent mechanisms. Am J Pathol 175: 605-615.
YASUOKA, H., JUKIC, D.M., ZHOU, Z., CHOI, A.M. and FEGHALI-BOSTWICK, C.A (2006a). Insulin-like growth factor binding protein 5 induces skin fibrosis: A nove murine model for dermal fibrosis. Arthritis Rheum 54: 3001-3010.

YASUOKA, H., YAMAGUCHI, Y. and FEGHALI-BOSTWICK, C.A. (2009b). The Profibrotic Factor IGFBP-5 Induces Lung Fibroblast and Mononuclear Cell Migration. Am J Respir Cell Mol Biol. 41: 179-188.

YASUOKA, H., ZHOU, Z., PILEWSKI, J.M., OURY, T.D., CHOI, A.M. and FEGHALIBOSTWICK, C.A. (2006b). Insulin-like growth factor-binding protein-5 induces pulmonary fibrosis and triggers mononuclear cellular infiltration. Am J Pathol 169: $1633-1642$

ZHANG, M., SMITH, E.P., KURODA, H., BANACH, W., CHERNAUSEK, S.D. and FAGIN, J.A. (2002). Targeted expression of a protease-resistant IGFBP-4 mutant in smooth muscle of transgenic mice results in IGFBP-4 stabilization and smooth muscle hypotrophy. J Biol Chem 277: 21285-21290.

ZHOU, R., FLASWINKEL, H., SCHNEIDER, M.R., LAHM, H., HOEFLICH, A., WANKE, R. and WOLF, E. (2004). Insulin-like growth factor-binding protein-4 inhibits growth of the thymus in transgenic mice. J Mol Endocrinol 32: 349-364.

\section{Further Related Reading, published previously in the Int. J. Dev. Biol.}

Epithelial-Mesenchymal Transitions in development and disease: old views and new perspectives

M. Angela Nieto

Int. J. Dev. Biol. (2009) 53: 1541-1547

Integrins contribute to the establishment and maintenance of cell polarity in the follicular epithelium of the Drosophila ovary Ana Fernández-Miñán, Laura Cobreros, Acaimo González-Reyes and María D. Martín-Bermudo Int. J. Dev. Biol. (2008) 52: 925-932

Cadherin-mediated cell-cell adhesion and tissue segregation in relation to malignancy

Ramsey A. Foty and Malcolm S. Steinberg

Int. J. Dev. Biol. (2004) 48: 397-409

Roles of insulin-like growth factors and their binding proteins in the differentiation of mouse tongue myoblasts Akira Yamane, Toki Urushiyama and Thomas G H Diekwisch

Int. J. Dev. Biol. (2002) 46: 807-816

IGF-I, IGF-II and insulin promote differentiation of spermatogonia to primary spermatocytes in organ culture of newt testes Y Nakayama, T Yamamoto and S I Abé Int. J. Dev. Biol. (1999) 43: 343-347

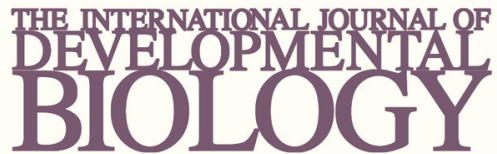

Volume 54 Nos. 6/7
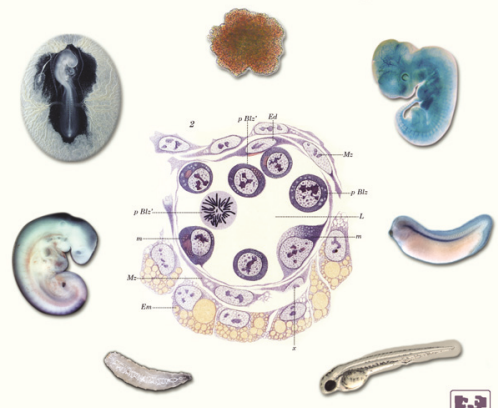

Developmental Hematopoiesis
5 yr ISI Impact Factor $(2010)=2.961$

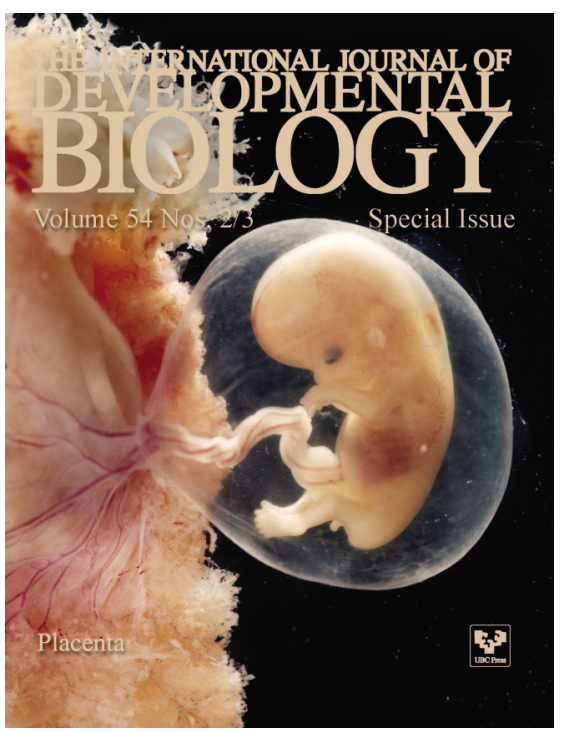

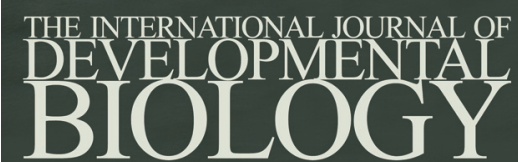

Volume 55 Nos. $4 / 5$ Special Issue

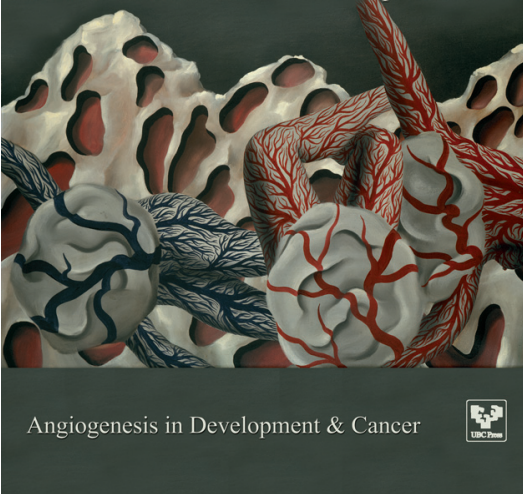

